Avalaible online: https://ejournal.iai-tribakti.ac.id/index.php/pgmi

Article doi: https://doi.org/10.33367/jiee.v3i2.1938

Submission: 2021-09-03 Review: 2021-09-28 Accepted: 2021-09-28

\title{
Berpikir Reflektif Siswa Kelas V-A MI Tanwirul Fuad Sumberjo dalam Memecahkan Masalah Matematika Materi Pecahan
}

\section{Reflective Thinking Students of Class V-A MI Tanwirul Fuad Sumberjo in Solving Math Problems in Fractional Materials}

\author{
Mohamad Muchib Azhari' ${ }^{1}$, Dianis Izzatul Yuanita ${ }^{2}$ \\ 12 Institut Agama Islam Tribakti Kediri \\ 1mahabbaalazhar@gmail.com; ${ }^{2}$ dianisizzatulyuanita@gmail.com
}

\begin{abstract}
So far, the tendency of mathematics teachers to not optimize students' mathematical thinking skills in learning, especially higher order thinking skills. One of the higher order thinking skills is reflective thinking. Reflective thinking is a directed and precise process in which individuals analyze, evaluate, motivate, gain deep meaning, using appropriate learning strategies. The reflective thinking ability according to Surbeck, Han and Moyer has 3 phases/levels, namely reacting, comparing, and contemplating. The purpose of this study was to describe students' reflective thinking skills in solving math problems with fractions in class V-A MI Tanwirul Fuad Sumberjo. As a source of data taken 6 students from 27 students. In this study data collection techniques used, namely tests, interviews and documentation. The data analysis technique used is qualitative data analysis with data reduction steps, data presentation, and drawing conclusions. Data analysis was carried out by: 1) presenting the data, 2) comparing the test result data with interviews conducted with students, and 3) concluding the data.
\end{abstract}

Keyword: Reflective Thinking, Problem Solving, Fraction

\begin{abstract}
Abstrak
Selama ini kecenderungan para guru matematika kurang mengoptimalkan kemampuan berpikir matematika siswa dalam pembelajaran, terutama kemampuan berpikir tingkat tinggi. Salah satu kemampuan berpikir tingkat tinggi adalah berpikir reflektif. Berpikir reflektif adalah proses terarah dan tepat dimana individu menganalisis, mengevaluasi, memotivasi, mendapatkan makna mendalam, menggunakan strategi pembelajaran yang tepat. Kemampuan berpikir reflektif menurut Surbeck, Han dan Moyer memiliki 3 fase/tingkatan yaitu reacting, comparing, dan contemplating. Tujuan dari penelitian ini adalah untuk mendeskripsikan kemampuan berpikir reflektif siswa dalam memecahkan masalah matematika materi pecahan di kelas $\mathrm{V}-\mathrm{A}$ MI Tanwirul Fuad Sumberjo. Sebagai sumber data diambil 6 siswa dari 27 siswa. Dalam penelitian ini teknik pengumpulan data yang digunakan, yaitu tes, wawancara dan dokumentasi. Teknik analisis data yang digunakan yaitu analisis data kualitatif dengan langkah-langkah reduksi data, penyajian data, dan penarikan kesimpulan. Analisis data dilakukan dengan cara: 1)
\end{abstract}


Oleh: Mohamad Muchib Azhari dan Dianis Izzatul Yuanita

menyajikan data, 2) membandingkan data hasil tes dengan wawancara yang dilakukan terhadap siswa, dan 3) menyimpulkan data.

\section{Kata Kunci: Berpikir Reflektif, Penyelesaian Masalah, Pecahan}

\section{Pendahuluan}

Matematika merupakan subjek yang sangat penting dalam sistem pendidikan di seluruh dunia. Negara yang mengabaikan pendidikan matematika sebagai prioritas utama akan tertinggal dari kemajuan segala bidang (terutama sains dan teknologi), dibanding dengan negara lainnya yang memberikan tempat bagi matematika sebagai subjek yang sangat penting. Karena, dengan menguasai matematika orang akan dapat belajar untuk mengatur jalan pemikirannya dan sekaligus belajar menambah kepandaiannya. Dengan kata lain, belajar matematika sama halnya dengan belajar logika, karena kedudukan matematika dalam ilmu pengetahuan adalah sebagai ilmu dasar atau ilmu alat. Sehingga, untuk dapat berkecimpung di dunia sains, teknologi, atau disiplin ilmu lainnya, langkah awal yang harus ditempuh adalah menguasai alat atau ilmu dasarnya, yakni menguasai matematika secara benar. Hal penting lainnya mengenai matematika adalah matematika melatih seseorang tentang cara berpikir dan bernalar dalam menarik kesimpulan. Misalnya dalam kegiatan penyelidikan, eksplorasi, eksperimen, menunjukkan kesamaan, perbedaan, konsistensi dan inkonsistensi.

Belajar melibatkan proses berpikir dalam diri setiap manusia, untuk mencapai berbagai macam kompetensi, keterampilan dan sikap. Berpikir selalu dilakukan oleh setiap orang atau individu, dengan demikian berpikir bersifat internal, muncul dalam diri individu dan berlangsung terusmenerus. Melalui berpikir, manusia dapat belajar meningkatkan kualitas hidupnya di masyarakat.

Manusia dapat berpikir karena manusia mempunyai bahasa, hewan tidak. Dalam arti yang terbatas berpikir itu tidak dapat didefinisikan. Tiap kegiatan jiwa yang menggunakan katakata dan pengertian selalu mengandung hal berpikir. Berpikir adalah satu keaktipan pribadi manusia yang mengakibatkan penemuan yang terarah kepada suatu tujuan. Kita berpikir untuk menemukan pemahaman atau pengertian yang kita kehendaki. Berpikir merupakan suatu hal yang dipandang biasa-biasa saja yang diberikan Tuhan 
kepada manusia, sehingga manusia menjadi makhluk yang dimuliakan. Ditinjau dari perspektif psikologi, berpikir merupakan cikal bakal ilmu yang sangat kompleks.

Memecahkan masalah matematika dalam penelitian ini didefinisikan suatu proses yang menggunakan pengetahuan, keterampilan, dan pemahaman yang dimiliki dalam menyelesaikan masalah yang tidak dapat diselesaikan dengan prosedur rutin akan tetapi harus dipecahkan dengan menggunakan pengetahuan, ketrampilan, dan pemahaman yang dimiliki untuk mencapai tujuan.

Pembelajaran pemecahan masalah dapat membantu siswa dalam mengembangkan kemampuan berpikir, memecahkan masalah dan keterampilan intelektual. Begitu pula, pemecahan masalah adalah "jantung" dari matematika (heart of mathematics). Akan tetapi, banyak fakta di lapangan yang masih menunjukkan bahwa pembelajaran matematika hanya terlihat sebagai suatu kegiatan yang monoton dan prosedural, yaitu guru menerangkan materi, memberi contoh, menugaskan siswa untuk mengerjakan latihan soal, mengecek jawaban siswa secara sepintas, selanjutnya membahas pemecahan soal yang kemudian dikerjakan kembali oleh siswa.

Berdasarkan pengamatan peneliti di MI Tanwirul Fuad, sebagian besar siswa masih belum mampu menerapkan berpikir secara reflektif dalam menyelesaikan masalah matematika. Mereka tidak menggunakan pengetahuan lamanya dalam menerapkan operasi hitung pecahan yang sudah pernah disampaikan di kelas 3, terutama operasi hitung penjumlahan dan pengurangan bentuk pecahan. Siswa masih belum memahami bagaimana mengoperasikan penjumlahan maupun pengurangan pecahan yang berpenyebut tidak sama ataupun bentuk pecahannya. Siswa tidak mengingat materi sifat-sifat operasi hitung pecahan yang telah dipelajarai di kelas 3. Hal itu terlihat ketika peneliti memberikan masalah tentang materi operasi penjumlahan dan pengurangan pecahan berbeda bentuk dan berpenyebut tidak sama ataupun bentuk pecahan yang lain. Siswa masih merasa kesulitan dalam menjumlahkan dan mengurangkan bentuk pecahan.

Dari pemaparan di atas, agar siswa mampu memecahkan masalah dalam soal matematika pada materi pecahan maka pendidik harus bisa menganalisis proses berpikir reflektif 
Oleh: Mohamad Muchib Azhari dan Dianis IzzatuL Yuanita

siswa. Sehingga pendidik dan siswa dapat melaksanakan pembelajaran sesuai tujuan pendidikan. Misalkan siswa diminta mengerjakan suatu persoalan dan kebanyakan hasil jawaban siswa yang belum benar dibahas secara bersama-sama, sehingga ada siswa yang belum memahami jawaban tersebut dan hanya mengikuti jawaban dari teman lainnya tanpa adanya pemahaman yang secara mendalam mengenai suatu permasalahan. Oleh karena itu penelitian mengenai hal tersebut dilakukan, yakni untuk mengetahui bagaimana proses dan kemampuan berpikir reflektif siswa dalam menyelesaikan soal-soal pecahan. Sehingga diharapkan peneliti mampu mengetahui bagaimana berpikir reflektif yang dilakukan siswa. Berdasarkan uraian di atas, maka peneliti mengambil judul "Kemampuan Berpikir Reflektif dalam Memecahkan Masalah Matematika Materi Pecahan pada Siswa Kelas VA MI Tanwirul Fuad Sumberjo."

\section{Metode}

Pendekatan yang digunakan dalam penelitian ini adalah pendekatan kualitatif. Penelitian kualitatif merupakan suatu metode berganda dalam fokus yang melibatkan suatu pendekatan interpretatif dan wajar ter- hadap setiap pokok permasalahannya. Penelitian ini merupakan penelitian studi kasus yang menggambarkan data kualitatif dan dideskripsikan untuk menghasilkan gambaran yang mendalam serta terperinci mengenai berpikir reflektif siswa kelas V-A MI Tanwirul Fuad Sumberjo dalam memecahkan masalah matematika materi pecahan. Penelitian ini berusaha memaparkan suatu gejala ataupun keadaan secara sistematis sehingga subjek penelitian menjadi lebih jelas. Sesuai dengan tujuan penelitian, melalui pendekatan kualitatif, semua fakta baik lisan maupun tulisan dari berbagai sumber data yang didapatkan dari partisipan akan diuraikan sejelas dan seringkas mungkin sehingga benar-benar mampu menjawab permasalahan pada penelitian ini. Oleh karena itu, jenis penelitian ini adalah penelitian studi kasus.

Lokasi yang digunakan pada penelitian ini adalah Madrasah Ibtidaiyah (MI) Tanwirul Fuad, dengan alamat di jalan Kauman no.1, Desa Sumberjo, Kecamatan Kandat, Kabupaten Kediri. Sedangkan subjek dari penelitian ini adalah siswa kelas V-A, karena pada kelas tersebut telah ditempuh materi pecahan yang sesuai 
dengan tujuan pada penelitian ini. Sebenarnya untuk kelas V terdapat dua kelas. Peneliti mengambil kelas V-A dikarenakan hasil pengamatan dan arahan dari guru matematika Bapak Aris Dinamika, S.Pd.I, bahwa pada kelas tersebut mempunyai kemampuan kognitif terutama pada bidang matematika lebih unggul dibandingkan dengan kelas yang lain, meskipun ada beberapa siswa yang kemampuannya masih rendah atau kurang mampu dalam menyelesaikan masalah terutama pelajaran matematika. Pada kelas V semester ganjil telah dilaksanakannya pembelajaran tentang materi pecahan dan pelaksanaan pada penelitian ini dengan cara peneliti memberikan tes untuk mengetahui kemampuan berpikir reflektif siswa. Untuk menentukan subjek penelitian, maka peneliti melakukan pemilihan subjek dengan cara menggunakan instrumen tes dan hasil nilai raport matematika semester ganjil.

Subjek penelitian yang akan dipilih adalah sebanyak 6 siswa. Dalam satu kelas diberikan tes tulis secara perorangan kemudian siswa dikelompokkan menjadi tiga kelompok, yaitu kelompok tinggi, sedang, dan rendah. Setelah ketiga kelompok tersebut terisi, kemudian dipilih 2 siswa dari masingel Bidayah: Journal of Islamic Elementary Education Volume 3, Nomor 2, September 2021 masing kelompok. Penggolongan siswa kedalam satu tipe gaya kognitif yakni: satu siswa yang ber-gaya reflektif diambil dari kelompok siswa reflektif yang catatan waktunya paling lama dan paling cermat (paling banyak benar) dalam menjawab seluruh masalah. Satu siswa bergaya impulsif diambil dari kelompok siswa impulsif yang catatan waktunya paling singkat tetapi paling tidak cermat/akurat (paling banyak salah) dalam menjawab seluruh masalah. Hal ini dilakukan supaya siswa yang terpilih benar-benar siswa reflektif atau siswa impulsif.

\section{Temuan dan Pembahasan}

\section{Temuan penelitian}

Penelitian tentang berpikir reflektif siswa dalam memecahkan masalah matematika ini bertujuan untuk mengetahui tingkat kemampuan berpikir reflektif siswa dalam memecahkan masalah pada materi pecahan. Untuk mengetahui tingkatan kemampuan tersebut peneliti menggunakan alat tes mencakup materi pecahan, dimana materi ini diajarkan di kelas $\mathrm{V}$ pada semester ganjil.

Pelaksanaan pengambilan data di lapangan diawali dengan melaksanakan observasi dengan tujuan untuk mengetahuai proses pembelajaran oleh guru yang dilaksanakan pada hari Senin 
Berpikir Reflekțif Siswa Kelas V-A MI Tanwirul Fuad Sumberjo dalam Memecahkan Masalah Matematika Materi Pecahan

Oleh: Mohamad Muchib Azhari dan Dianis IzzatuL Yuanita

tanggal 18 Februari 2020. Pelaksanaan observasi ini diamati langsung oleh peneliti dan teman sejawat. Pada saat observasi peneliti mengamati proses kegiatan pembelajaran yang dilakukan oleh guru dan juga aktivitas dari siswa selama pembelajaran berlangsung.

Pertemuan selanjutnya pada hari Selasa, tanggal 3 Maret 2020 peneliti memberikan soal tes kepada semua siswa, dan soal yang diberikan terdiri dari 3 poin yaitu nomor 1, 2, dan 3 yang dikerjakan siswa mulai dari pukul 08.30 sampai dengan pukul 09.50 WIB. Tujuan penelitian ini adalah mendeskripsikan tingkat kemampuan berpikir reflektif siswa dalam menyelesaikan soal terkait materi pecahan yang meliputi penjumlahan, pengurangan, perkalian dan pembagian bentuk pecahan. Dari hasil pengamatan peneliti, pada awal pelaksanan tes tulis secara umum siswa mengerjakan dengan mandiri dan sungguh-sungguh, hal ini karena peneliti berkeliling untuk mengamati siswa, dan sebagian besar siswa sudah bisa mengerjakan soal sendiri meskipun ada beberapa yang belum mengerti cara mengerjakannya. Sekitar 30 menit kemudian siswa mulai agak ramai karena sedikit mengalami kendala pada soal nomor 2 dan 3 .
Pelaksanaan wawancara dilakukan selama dua kali yaitu pada hari Kamis 5 Maret 2020 pada jam istirahat (pukul 09.40-10.00 WIB) kepada dua siswa. Untuk 4 siswa dari kemampuan sedang dan rendah serta guru pengampu pada hari Sabtu tanggal 7 Maret 2020 yang pada saat itu ada jam kosong sampai selesai (pukul 09.00-10.00 WIB). Untuk memudahkan proses wawancara, peneliti menggunakan alat perekam dan menggunakan alat tulis untuk menulis hasil wawancara selain bukti rekaman misalkan keterangan yang ditulis tanpa disuarakan. Pelaksanaan wawancara ini dilakukan di lingkungan MI Tanwirul Fuad Sumberjo, yakni di Masjid dan di depan kelas. Hal ini mengingat bahwa pelaksanaan wawancara yang pada saat jam pelajaran, sehingga memudahkan untuk mencari tempat yang lebih nyaman. Adapun rincian subjek wawancara dan transkrip wawancara disajikan dalam lampiran.

Peserta yang mengikuti tes tulis sebanyak 25 siswa dari 27 siswa, dan 2 siswa lainnya tidak masuk sekolah sehingga tidak mengikuti tes dikarenakan sakit. Pengkodean siswa dalam penelitian ini digunakan untuk mempermudah analisis yang dilakukan oleh peneliti. Pengkodean siswa dalam 
penelitian ini didasarkan pada inisial nama siswa.

Peneliti menggunakan hasil wawancara dengan siswa dan hasil wawancara dengan guru matematika kelas V-A MI Tanwirul Fuad Sumberjo. Hasil wawancara dengan siswa, digunakan peneliti sebagai dasar untuk mengetahui strategi yang digunakan oleh siswa dalam memecahkan masalah metematika materi fungsi. Adapun wawancara yang dilakukan dengan guru bertujuan untuk mengetahui strategi guru dalam menjelaskan materi pecahan kepada siswa.

Hasil dari pengumpulan data yaitu hasil pengamatan peneliti sebagai instrumen, hasil kerja siswa dan wawancara seperti dikemukakan di atas dan selanjutnya di analisis. Berikut pembahasan dari 3 kategori subjek tersebut diantaranya:

Proses berpikir reflektif siswa dalam pemecahan masalah pecahan yang berkemampuan matematika tinggi Berdasarkan dari data penelitian, maka peneliti dapat menganalisis kemampuan berpikir reflektif siswa melalui tes tulis serta membandingkannya dengan hasil wawancara untuk memperkuat keabsahannya.

Deskripsi aspek berpikir reflektif dalam pemecahan masalah pertama adalah el Bidayah: Journal of Islamic Elementary Education Volume 3, Nomor 2, September 2021 mengidentifikasi fakta yang telah dilakukan. Berdasarkan respon subjek pada aspek ini, proses berpikir reflektif subjek yaitu menjelaskan identifikasi fakta yang telah dilakukan, subjek pada aspek ini menjelaskan dengan baik. Hasil wawancara subjek menjelaskan "Nomor satu menjelaskan tentang berapa banyak kain yang diperlukan untuk membuat 2 celana panjang dan 2 celana pendek, jika 1 celana panjang membutuhkan kain 1 1/8 meter, sedangkan 1 kemeja lengan pendek 1 $1 / 2$. Diketahui untuk membuat celana panjang membutuhkan kain 1 1/8 meter, sedangkan 1 kemeja lengan pendek 1 1/2 meter". Dari respon tersebut terlihat bahwa subjek dalam menjelaskan identifikasi fakta yang telah dilakukan, subjek melakukannya dengan baik. Petikan wawancara tersebut menunjukan bahwa subjek mengetahui apa yang di tanyakan dalam soal dan subjek menjelaskannya dengan baik.

Aspek berikutnya adalah mengidentifikasi pertanyaan yang telah dilakukan, berpikir reflektif yang dimaksudkan dalam hal ini adalah subjek bisa menjelaskan tentang identifikasi fakta yang telah dilakukan, subjek menjelaskan bahwa pernah menghadapi permasalahan yang sama sebelumnya 185 
Oleh: Mohamad Muchib Azhari dan Dianis IzzatuL Yuanita

dan mampu mengaitkan soal yang Ketika peneliti menanyakan "Bagaimana pernah dihadapi dengan soal yang sedang dihadapi saat ini. Hasil petikan wawancara terhadap subjek yaitu: "Soalnya juga persis kayak gini menanyakan tentang soal cerita penjumlahan penyebut yang berbeda, mungkin hanya angkanya saja yang berbeda. Sama-sama menanyakan nilai penjumlahan bilangan pecahan dan bilangan bulat." Berdasarkan petikan wawancara di atas menunjukkan bahwa subjek telah melewati fase comparing dengan menggunakan suggestion (saran) berupa ide yang dirancang sesuai pengetahuan yang pernah didapat untuk memahami soal dengan yang ditanyakan.

Langkah melaksanakan rencana pemecahan dalam menyelesaikan masalah pecahan, melakukannya berpikir reflektif dengan baik. Hal ini menunjukkan bahwa subjek berpikir reflektif yaitu subjek memiliki informasi dan mampu menjelaskan tentang keterampilan perhitungan. Subjek sudah memperoleh materi pecahan, yaitu penjumlahandan pengurangan. Informasi ini menunjukkan bahwa dalam merespon soal subjek sudah memiliki informasi tentang cara menyelesaikan operasi hitung pecahan. 
memeriksa kembali tidak melakukan kesalahan.

Proses berpikir reflektif siswa dalam pemecahan masalah pecahan yang berkemampuan matematika sedang

Berdasarkan dari data penelitian, maka peneliti dapat menganalisis kemampuan berpikir reflektif siswa melalui tes tulis serta membandingkannya dengan hasil wawancara untuk memperkuat keabsahannya.

Langkah memahami masalah yaitu mengidentifikasi fakta yang telah dilakukan merupakan salah satu aspek yang terungkap dalam hasil wawancara, dan pengamatan. Pada aspek ini subjek S-4 menjelaskan dengan baik. Berdasarkan respon subjek menjelaskan" Yang diketahui tentang panjang talang rumah bagian depan $51 / 4$ meter, bagian dapur 3 3/8 meter, talang yang tersedia 4 1/2 meter. (Sambil menunjuk hasil pekerjaannya). Berarti yang ditanyakan tadi tentang kekurangan talang yang harus dibeli pak Harjo. Deskripsi aspek berpikir reflektif dalam pemecahan masalah soal nomor 2 adalah mengidentifikasi fakta yang telah dilakukan. Berdasarkan respon subjek pada aspek ini, proses berpikir reflektif subjek yaitu menjelaskan identifikasi fakta yang telah dilakukan, subjek pada aspek ini el Bidayah: Journal of Islamic Elementary Education Volume 3, Nomor 2, September 2021 menjelaskan dengan cukup baik, meskipun ada beberapa hal yang belum bisa dipahami oleh subjek. Subjek sudah merasa cukup dengan apa yang diketahui dari soal untuk menjawab yang ditanyakan. Dalam mengidentifikasi pertanyaan yang telah dilakukan. Pada aspek ini subjek mengetahui dan mengerti apa yang ditanyakan dalam soal nomor 2. Respon subjek yaitu "Menanyakan tentang kekurangan panjang talang yang harus dibeli pak Harjo untuk dipasang di rumahnya?".

Aspek berikutnya adalah mengidentifikasi pertanyaan yang telah dilakukan, berpikir reflektif yang dimaksudkan dalam hal ini adalah subjek bisa menjelaskan tentang identifikasi fakta yang telah dilakukan, subjek menjelaskan bahwa pernah menghadapi permasalahan yang sama sebelumnya dan mampu mengaitkan soal yang pernah dihadapi dengan soal yang sedang dihadapi saat ini. Hasil petikan wawancara terhadap subjek ketika peneliti menanyakan "Apakah pernah menghadapi soal yang hampir sama ? coba sebutkan !. Respon subjek. "sudah". "Coba jelaskan langkahlangkah penyelesaianmu ini". Respon subjek. "Soalnya tentang sebuah tali yang ukurannya berbeda, kemudian 
Oleh: Mohamad Muchib Azhari dan Dianis Izzatul Yuanita

dipotong beberapa bagian, lalu disuruh soal subjek sudah memiliki informasi mencari sisa panjang tali yang masih ada.". Berdasarkan petikan wawancara di atas menunjukkan bahwa subjek telah melewati fase comparing bagian a dan b, karena subjek sudah pernah menghadapi permasalahan yang hampir sama sebelumnya. Namun subjek mencoba menjelaskan dari jawabannya tersebut dari pengetahuan yang dimilikinya menggunakan suggestion (saran) berupa ide yang dirancang sesuai pengetahuan yang pernah didapat untuk memahami soal dengan yang ditanyakan.

Langkah merencanakan pemecahan, yaitu menjelaskan tentang bagaimana memilih operasi dalam pemecahan masalah pecahan. Selanjutnya, melaksanakan rencana pemecahan dalam menyelesaikan masalah pecahan, melakukannya berpikir reflektif dengan baik. Hal ini menunjukkan bahwa subjek berpikir reflektif yaitu subjek memiliki informasi dan mampu menjelaskan tentang keterampilan perhitungan. Subjek sudah memperoleh materi pecahan, yaitu dengan mengingat materi operasi penjumlahan dan perkalian pecahan campuran. Informasi ini menunjukkan bahwa dalam merespon tentang pecahan.

Berdasarkan uraian di atas, dalam merencanakan pemecahan, terdapat beberapa aspek yang dapat diungkap dan dapat dikaitkan dengan deskriptor berpikir reflektif yaitu: subjek menjelaskan tentang bagaimana menyusun dan merepresentasikan data, subjek menjelaskan tentang bagaimana memilih operasi, dan subjek kesulitan menjelaskan tentang bagaimana langkah awal dalam pemecahan masalah, karena masih baru menghadapi soal yang demikian.

Selanjutnya subjek menyadari ada kesalahan pada saat menggunakan keterampilan perhitungan dan memperbaikinya. Subjek melakukan kesalahan pada saat menghitung, namun subjek langsung memperbaikinya, hal ini terlihat dari respon subjek yaitu “Oo, iya masih salah. Berarti ini yang dijumlahkan 5 1/4+3 3/8 ditambahkan dulu bilangan depannya, kemudian pecahannya disamakan penyebut". Pada aspek ini subjek memperbaiki jawabannya yang salah dan peneliti menanyakan "Sudah tahu letak kesalahannya dimana?”. Respon subjek yaitu "Sudah. Nilai pecahannya yang salah menulis". Subjek mampu 
memperbaiki dan menjelaskan kesalahan dari jawaban, sehingga subjek memenuhi fase contemplating bagian $\mathrm{c}$. Sehingga subjek memenuhi fase indikator berpikir reflektif.

Proses berpikir reflektif siswa dalam pemecahan masalah pecahan yang berkemampuan matematika rendah

Berdasarkan dari data penelitian, maka peneliti dapat menganalisis kemampuan berpikir reflektif siswa melalui tes tulis serta membandingkannya dengan hasil wawancara untuk memperkuat keabsahannya.

Pada soal nomor 3 siswa mampu menuliskan apa yang ditanyakan dalam soal, sehingga menunjukkan bahwa subjek memenuhi fase reacting bagian a. Hal ini terlihat dari respon siswa ketika ditanya oleh peneliti tentang "Apa yang ditanyakan pada soal nomor 3?" respon siswa yaitu "Luas tanah pak Made yang ditanami bunga". Siswa mampu menuliskan apa yang diketahui dalam soal, hal ini menunjukkan bahwa subjek memenuhi fase reacting bagian $b$. Langkah berikutnya siswa tidak mampu menuliskan langkah pengerjaan dan menyelesaikan soal, sehingga subjek tidak memenuhi fase comparing dan fase contemplating. Hal ini diperkuat dari respon siswa yang ketika ditanya el Bidayah: Journal of Islamic Elementary Education Volume 3, Nomor 2, September 2021
"Lalu apa hubungan antara yang diketahui dengan yang ditanyakan? Kemudian respon siswa "Penjumlahan dan pengurangan pecahan mungkin". Subjek sedikit ragu-ragu dalam menjawab. Selain itu siswa juga belum pernah menghadapi soal yang hampir sama dengan yang sedang dihadapi saat ini. Seperti pertanyaan peneliti tentang "Apakah pernah menghadapi soal yang hampir sama? coba sebutkan !" rsspon siswa "belum pernah". Siswa juga tidak bisa menjelaskan dan menyelesaikan masalah yang sedang dihadapinya. Ketika peneliti meminta untuk mengerjakan, siswa tidak bisa karena belum tahu caranya. "Coba jelaskan jawaban yang kamu tuliskan ini”. Jawaban siswa "Belum saya kerjakan".

Dari ketiga kategori tersebut, siswa mempunyai tingkat berpikir yang berbeda satu dengan yang lain. Dengan pengamatan hasil tes tulis dan wawancara berdasarkan indikator tersebut akan diketahui kemampuan berpikir reflektif siswa. Materi yang digunakan peneliti untuk menguji kemampuan berpikir reflektif siswa adalah materi tentang pecahan. Materi operasi hitung pecahan merupakan materi lanjutan dari materi bilangan pecahan yang sudah pernah dibahas di klas 3. Berdasarkan pemahaman siswa 
Oleh: Mohamad Muchib Azhari dan Dianis Izzatul Yuanita

tentang pecahan, siswa akan menjelaskan 1 metode yang

memahamioperasi hitung pada bentuk pecahan. Karena saling keterkaitannya materi pecahan dengan operasi hitungnya. Pengalaman siswa dalam mengerjakan soal yang pernah dihadapi juga akan mempengaruhi kemampuan berpikir reflektif siswa.

\section{Pembahasan}

Dari data analisis di atas, maka peneliti dapat membandingkan kemampuan berpikir reflektif siswa dalam memecahkan masalah materi pecahan pada siswa kategori tinggi, sedang, dan rendah sebagai berikut:

a. Pada penyelesaian soal untuk siswa kategori tinggi, siswa berada pada T3 yaitu kategori reflektif. Kemampuan berpikir reflektif siswa tersebut adalah sangat tinggi. Hal ini terbukti karena pada semua soal siswa dikatakan reflektif. Siswa dengan kemampuan berpikir reflektif pada kategori reflektif memiliki beberapa kecenderungan dalam menye-lesaikan soal cerita yakni menye-butkan apa yang diketahui dan yang ditanya dengan benar, dapat mem-buat dan mendefinisikan model matematika dengan benar, dapat dianggap efektif dan pernah dilakukan, dan dapat memilih 1 metode yang dianggap efektif yang akan dilakukan. Selain itu, juga memiliki kecen-derungan dapat menghubungkan masalah yang pernah dihadapi dengan masalah operasi penjum-lahan yang dihadapi. Dapat pula menyelesaikan soal dengan benar menggunakan metode yang telah dipilih, mendeteksi kesalahan dengan melakukan koreksi minimal 1 kali, dan dapat membuat kesimpulan dengan benar.

b. Pada penyelesaian soal untuk siswa kategori sedang, siswa juga berada pada T3 yaitu reflektif. Kemampuan berpikir reflektif siswa tersebut adalah tinggi. Hal ini terbukti karena hampir semua soal siswa dikatakan reflektif dan terdapat satu soal dimana siswa dikatakan cukup reflektif. Siswa dengan kemampuan berpikir reflektif tinggi memiliki beberapa kecenderungan dalam menyelesaikan soal cerita yakni dapat menyebutkan apa yang diketahui dan yang ditanya 
dengan benar, dapat menjelaskan 1 metode yang dianggap efektif dan pernah dilakukan, dan dapat memilih 1 metode yang dianggap efektif yang akan dilakukan. Selain itu, juga memiliki kecenderungan dapat menghubungkan masalah yang ditanya dengan masalah pecahan, dapat pula menyelesaikan soal dengan benar menggunakan metode yang telah dipilih, mendeteksi kesalahan dengan melakukan koreksi meskipun hanya 1 kali, memperbaiki dan menjelaskan kesalahan tersebut dan dapat membuat kesimpulan dengan benar dari kesalahan yang telah diperbaiki.

c. Pada penyelesaian soal untuk siswa kategori kurang, siswa berada pada T1 yaitu kurang reflektif. Kemampuan berpikir reflektif siswa tersebut adalah rendah. Hal ini terbukti karena hampir sebagian besar analisis jawaban siswa dikatakan kurang reflektif dalam merespon jawaban. Terdapat 1 soal di mana siswa pada kategori cukup reflektif dan 1 soal kategori reflektif. Siswa dengan kemampuan berpikir reflektif pada kategori rendah memiliki beberapa kecenderungan dalam menyelesaikan soal cerita yakni menyebutkan apa yang diketahui dan yang ditanya dengan benar, dapat membuat dan mendefinisikan model matematika dengan benar meskipun untuk soal tertentu saja. Kecenderungan lain yang dapat diketahui adalah siswa pada kategori rendah tidak dapat mengingat metode yang pernah dilakukan, tidak dapat memilih metode yang dianggap efektif dan yang akan dilakukan. Selain itu, juga memiliki kecenderungan tidak dapat menghubungkan masalah yang ditanya dengan soal operasi pecahan, dapat menyelesaikan soal dengan benar dengan sedikit kesalahan, tidak mendeteksi kesalahan dan tidak melakukan koreksi, tidak dapat memperbaiki dan menjelaskan kesalahan tersebut serta tidak dapat membuat kesimpulan dengan benar.

Ada tiga fase yang harus dilewati oleh siswa untuk dikatakan mempunyai kemampuan berpikir reflekti yaitu fase reacting, comparing, dan contemplating. Jika siswa hanya mampu melewati fase 
Oleh: Mohamad Muchib Azhari dan Dianis Izzatul Yuanita

reacting saja maka siswa dikategorikan kurang reflektif. Jika siswa mampu melewati fase reacting dan comparing maka siswa dikategorikan cukup reflektif. Jika siswa mampu melewati fase reacting, comparing dan contemplating maka siswa dikategorikan reflektif. Dilihat dari hasil tes tulis dan wawancara siswa yang melewati semua tahapan fase pada indikator kemampuan berpikir refletif, menunjukkan bahwa mampu menyeleksi dan menggunakan pengetahuan yang telah dimiliki untuk menyelesaikan masalah yang sedang dihadapi. Hal ini sejalan dengan pengertian berpikir reflektif yang dikemukakan beberapa ahli.

Kemampuan tingkat berpikir reflektif siswa juga dipengaruhi oleh ketelitian siswa dalam membaca dan menjawab soal. Selain itu, jawaban siswa dari pertanyaan yang diajukan oleh peneliti pada saat wawancara juga mempengaruhi kemampuannya dalam memahami materi pecahan. Dimana pada pemahaman materi yang dimiliki siswa termasuk dalam kemampuan berpikir reflektif, karena diharapkan siswa dapat mengaitkan soal yang diberikan dengan materi atau soal yang pernah dihadapi sebelumnya. Dari hasil observasi dan analisis jawaban siswa di atas, peneliti dapat memahami bahwa semua siswa belum tentu dapat teliti dalam mencermati soal yang diberikan.

\section{Kesimpulan}

Berdasarkan hasil penelitian bahwa kemampuan dalam berpikir reflektif baik itu kepada siswa maupun guru perlu diketahui dan dikembangkan, karena sangat diperlukan dalam kehidupan sehari-hari. Misalkan dapat membantu siswa dalam menyelesaikan masalah baru yang mungkin pernah dihadapi sebelumnya. dimana pada salah satu indikator dalam kemampuan berpikir reflektif diharapkan siswa mampu mendeteksi kesalahan, sehingga bisa membantu mendeteksi suatu jawaban dari masalah tersebut sudah benar atau belum, sehingga dapat diperbaiki jika ada kesalahan dalam pemecahan masalahnya.

Berdasarkan fokus penelitian serta hasil penyajian data, temuan penelitian, dan pembahasan penelitian pada bab IV yang telah diuraikan, maka diperoleh kesimpulan berdasarkan jawaban tertulis siswa dan hasil wawancara siswa kelas V-A MI Tanwirul Fuad Sumberjo dalam memecahkan masalah materi pecahan sebagai berikut : 
1. Ada beberapa fase yang harus dilewati untuk mengetahui tingkat berpikir reflektif siswa. Fase tingkat berpikir reflektif yaitu fase reacting, comparing, dan contemplating. Berdasarkan hasil penelitian yang telah dilaksanakan di lapangan menunjukkan bahwa, ada beberapa siswa yang mampu melewati semua fase kemampuan berpikir reflektif. Ada juga yang melewati fase reacting dan comparing saja, dan ada juga yang hanya melewati fase reacting saja. Membutuhkan suatu patokan dalam pengukuran, dalam hal ini peneliti menggunakan indikator.

2. Kemampuan berpikir reflektif siswa pada setiap nomor soal memenuhi fase atau tahapan yang cukup berbeda.

3. Terdapat siswa yang kurang teliti dalam menjawab soal dengan metode yang digunakannya sehingga mempengaruhi kemampuan tingkat berpikir reflektif siswa.

4. Kegiatan wawancara yang dilakukan dengan bimbingan dan pengarahan dari peneliti ternyata mampu memberikan kesadaran pada siswa tentang proses pemecahan masalah dan memperbaiki kesalahan yang mereka lakukan.
Hasil dari kemampuan tingkat berpikir reflektif siswa menunjukkan bahwa:

1. Siswa yang memiliki kemampuan tinggi, siswa berada pada T3 yaitu siswa dalam kategori reflektif pada setiap respon. Pada tingkat ini siswa mampu memenuhi semua fase berpikir reflektif yaitu reacting, comparing, dan contemplating pada setiap jawaban soal.

2. Siswa yang memiliki kemampuan sedang, siswa juga berada pada T3 yaitu siswa dalam kategori reflektif pada setiap respon. Pada tingkat ini siswa mampu memenuhi fase berpikir reflektif yaitu reacting, comparing, dan contemplating. Terdapat satu soal dimana siswa berada pada kategori cukup reflektif yaitu siswa hanya memenuhi fase reacting dan comparing.

Siswa yang memiliki kemampuan rendah, siswa berada pada T1 yaitu siswa dalam kategori kurang reflektif. Pada tingkat ini sebagian besar siswa hanya mampu memenuhi fase reacting. Terdapat satu soal siswa dalam kategori reflektif dan cukup reflektif yaitu siswa memenuhi 3 fase berpikir reflektif dan cukup reflektif. 
Berpikir Reflekțif Siswa Kelas V-A MI Tanwirul Fuad Sumberjo dalam Memecahkan Masalah Matematika Materi Pecahan

Oleh: Mohamad Muchib Azhari dan Dianis Izzatul Yuanita

\section{Daftar Pustaka}

Arifin, Zainal. 2011. Penelitian

Pendidikan Metode dan Paradigma

Baru. Bandung: Remaja

Rosdakarya.

Fadhilah, Millatul. 2015. Analisis

Berpikir Reflektif Siswa dalam

Memecahkan Masalah Matematika

Materi Garis Singgung Lingkaran

Kelas VIII A

Masykur Ag, Moch \& Fathani, Abdul

Halim . 2008. Mathematical

Intelligence Cara Cerdas Melatih

Otak Kanan dan Menanggulangi

Kesulitan Belajar. Jogjakarta: Ar-

Ruzz Media.

Moleong, Lexy J. 2011. Metode

Penelitian Kualitatif. Bandung:

Remaja Rosdakarya.

Mulyana, Deddy. 2008. Metodologi

Penelitian Kualitatif. Bandung:

Remaja Rosdakarya.

Nisak, Lailatun. 2013. Analisis

Kemampuan Berpikir Reflektif

Siswa dalam Memecahkan

Masalah Berbentuk Semantik,

Figural dan Simbolik pada Pokok

Bahasan Fungsi Kelas XI IPA di

MAN Nglawak Kertosono Nganjuk.

Skripsi Jurusan Pendidikan

Matematika IAIN Sunan Ampel.
Noer, Sri Hastuti. 2008. Problem-Based

Learning dan Kemampuan

Berpikir Reflektif dalam

Pembelajaran Matematika.

Semnas Matematika dan

Pendidikan Matematika.

Purwanto, Ngalim. 2013. Psikologi

Pendidikan. Bandung: Remaja

Rosdakarya.

Suharna, Hery, dkk. 2013. Berpikir

Reflektif Mahasiswa. KNPM V,

Himpunan Matematika Indonesia.

Suharna, Hery. 2012. Berpikir Reflektif

(Reflective Thinking) Siswa SD

Berkemampuan Matematika

Tinggi dalam Pemahaman

Masalah Pecahan. Ternate:

Seminar Nasional Matematika dan

Pendidikan Matematika FMIPA

UNY Yogyakarta.

Tanzeh, Ahmad. 2009. Pengantar

Metode Penelitian. Yogyakarta:

Teras.

Widiawati, Restu. 2016. Kemampuan

Berpikir Reflektif Siswa dalam

Memecahkan Masalah Matematika

pada Materi Sistem Persamaan

Linier Dua Variabel (SPLDV)

Berdasarkan Gender Kelas VIII Di

MTs Negeri Tanjunganom. 